\title{
Research on the Incentive of "Chinese Spirit" to Higher Vocational Students in the Epidemic Situation
}

\author{
Huifang Guo ${ }^{a},{ }^{*}$, Denghong Wang ${ }^{b}$, Fangfang Yin ${ }^{c}$ \\ Zhejiang Tongji Vocational College of science and technology, Hangzhou, Zhejiang 3112312, \\ China \\ a, * 32970400@qq.com, b 782851368@qq.com, c 61681034@qq.com
}

\begin{abstract}
The sudden epidemic has changed people's way of production and life, but the antiepidemic also fully embodies the "Chinese spirit". Many extraordinary stories have emerged in the epidemic, which bring us a sense of immersive participation and make them more infectious than usual. This paper discusses the "Chinese spirit" embodied in the epidemic and deeds and their incentives to students, and hope to extend the path exploration of the cultivation of "Chinese spirit" of higher vocational students for your reference and evaluation.
\end{abstract}

Keywords: Epidemic Situation; Chinese Spirit; Incentive.

\section{Foreword}

The story is transmitted to students through multi-dimensional ways, which has brought strong educational effects to students. Students, their families and friends also participate in this "battle" in a variety of ways. Investigating, summarizing and publicizing typical "battle" stories to students will make students feel the same and play a strong incentive effect.

\section{2. "Chinese Spirit" is Rooted in the Background of the Current Era}

At the beginning of the 2020, at the beginning of the year of the gengzi rat, the whole country swept over the land of China. The beating of the infection figures tightened everyone's heart, shops closed, traffic was paralyzed, and life passed away. The havoc seemed to be coming to the eye. At the most critical juncture, the people's Liberation Army formed a huge force around the party and controlled the stable economic and social life. This spirit is the "Chinese spirit" that has curbed the spread of the epidemic.

The epidemic is not only a disaster, but also a sharpening stone for our national spirit. Anything that cannot defeat us will make us stronger. The great Chinese spirit has been fully demonstrated in the epidemic prevention and control, and has gathered a strong spiritual force to overcome the epidemic.

On January 24, hundreds of excavators arrived at the construction site of Wuhan huoshenshan hospital on New Year's Eve to start land leveling. A race against time began. After 10 days, we will witness a miracle. On the second day, the project of huoshenshan hospital was officially started, on the third day, the foundation drawings of 6 nursing units and general drawings of water and electricity were completed, on the fourth day, the site leveling was completed, and the first batch of container plank houses were hoisted and built on the 5th day, the steel structure of the double-layer ward area began to take shape. On the 6th day, the installation of more than 300 box type plank house skeletons was completed, and the electromechanical pipeline operation was carried out simultaneously. On the 7th day, the laying of HDPE membrane was fully completed, and the equipment hoisting in the sewage treatment room was carried out simultaneously. On the 8th day, the assembly of $90 \%$ containers had been completed, and the movable plank house skeletons were installed with an area of 3000 square meters. On the 9th day, the installation of medical supporting equipment was fully carried out, and on the 10th day Huoshenshan hospital was officially handed over to the medical workers of the people's army. Tens of millions of people "cloud supervisors" on the Internet participated in the whole process of this miracle. The engineers were hurried and silent, but they 
created the miracle of completing 1000 negative pressure beds in ten days. Chinese spirit: the power of one heart and one mind.

We are lucky to live in this era when the Chinese nation is forging ahead. We have experienced the country, the party and every Chinese through many hardships. However, the progress of science and technology and the lack of information technology have given us a greater vision. Ordinary, we stick to our posts or stay at home and do our jobs well. This is the Chinese spirit, the spirit of the Chinese people in this era.

\section{3. "Chinese Spirit" Comes from the "War Epidemic" around Us}

COVID-19 has influenced and changed the lives of each of us, from the daily experience of war and epidemic, and thus refining the spirit of "China" which appears more real and cordial. "In the first few days of the epidemic, I helped write the entry and exit pass for the local population in the village. I was always fighting against the traditional characters on the population book. After that, I used an infrared thermometer to measure the temperature of the vehicle personnel at the assigned intersection. Every morning, someone would boil water and send it to the garrison. The whole village was united to fight the epidemic. I realized that I made strong efforts and paid money The power of unity is so strong. " "The sudden epidemic stopped me from living a full life. I didn't know what to do for a moment. Spending every day in TV dramas and microblogs made people feel nihilistic. I like English and reading. I hope to make what I like to do a habit, so I started my English punch in life. Every challenge has different gains. Thank myself for adhering to it Participate, focus on practice, and seriously complete the clock out."

China's official account is the same as China's Zhejiang science and Technology University. The above contents are from the Tongzhi science and Technology University of Career Academy, the same public building, the plain language, the real epidemic life, the inner unity and the perseverance and progress is perfectly consistent with the "Chinese spirit". There is no lack of "China spirit" in life, but we need to sublimate it. This case from around us makes students feel more naturally "Chinese spirit". Value orientation and better incentive effect.

Table 1. What actions have you done to embody the Chinese spirit from this epidemic?

\begin{tabular}{|c|c|}
\hline option & proportion \\
\hline Donate materials to areas with serious epidemic situation & $55.27 \%$ \\
\hline Refuse to eat wild animals and protect nature & $80.33 \%$ \\
\hline Help people around you master the necessary epidemic prevention measures & $76.81 \%$ \\
\hline Cheer for the front-line medical staff through the network platform & $70.73 \%$ \\
\hline Participate in community volunteer service & $44.96 \%$ \\
\hline Actively exercise and bring positive energy to the society & $63.23 \%$ \\
\hline Popular science epidemic prevention knowledge & $61.12 \%$ \\
\hline Try to stay at home and reduce going out & $72.37 \%$ \\
\hline Comply with the requirements of the state, community and school during epidemic prevention & $65.34 \%$ \\
\hline other & $1.17 \%$ \\
\hline
\end{tabular}

\section{Investigation on the Incentive of "Chinese Spirit" to Higher Vocational Students}

In order to understand the "Chinese spirit" people and things impressed by college students in the epidemic and the impact of these "Chinese spirit" on students, a questionnaire on "Chinese spirit in 
the epidemic" was distributed to students majoring in architecture, and a total of 427 questionnaires were received. The questions cover the connotation, understanding channels, impact on themselves and whether to accept the "Chinese spirit" "Chinese spirit" into teaching.

The survey shows that $98.83 \%$ of the students have experienced the "Chinese spirit". Among them, $36.07 \%$ of the students can describe the "Chinese spirit" in detail, and $52.22 \%$ of the students know the core content of the "Chinese spirit". The students have experienced the "Chinese spirit" in the epidemic situation Including: patriotism, unity, dedication, loyalty, hard work, reform and innovation, responsibility, diligence and courage, courage to take responsibility, modesty and courtesy, etc. among them, the students believe that the most important core of the Chinese spirit is patriotism.

Table 2. What do college students think is the connotation of Chinese spirit?

\begin{tabular}{|c|c|}
\hline option & proportion \\
\hline Patriotic & $97.66 \%$ \\
\hline unite & $93.44 \%$ \\
\hline Love and dedication & $89.46 \%$ \\
\hline loyal & $84.07 \%$ \\
\hline Work hard & $85.95 \%$ \\
\hline Reform and innovation & $82.67 \%$ \\
\hline be responsible for & $76.58 \%$ \\
\hline Industrious and brave & $82.20 \%$ \\
\hline Dare to take responsibility & $84.31 \%$ \\
\hline Humility and comity & $70.26 \%$ \\
\hline other & $1.17 \%$ \\
\hline
\end{tabular}

The students learned that the channels of Chinese spirit include family education, school education, TV columns, network media, books and periodicals, community publicity, daily communication, etc. the top three are school education, network media and TV columns, of which school education accounts for $79.16 \%$, network media accounts for $72.13 \%$ and TV columns account for $69.56 \%$.

Table 3. How did college students learn about the Chinese spirit

\begin{tabular}{|c|c|}
\hline option & proportion \\
\hline home education & $59.95 \%$ \\
\hline School education & $79.16 \%$ \\
\hline tv column & $69.56 \%$ \\
\hline Network media & $72.13 \%$ \\
\hline Books and newspapers & $42.62 \%$ \\
\hline Community publicity & $35.60 \%$ \\
\hline Daily communication & $34.89 \%$ \\
\hline other & $4.45 \%$ \\
\hline
\end{tabular}

The students experienced the "Chinese spirit" in medical staff, youth, grass-roots workers, people around them, the army and national staff. Among them, medical staff and grass-roots workers had the deepest impact on the students.

$84.54 \%$ of the students thought that the Chinese spirit in the epidemic had a great impact on them. $93.68 \%$ of the students were "proud of their motherland", $84.54 \%$ of the students said they would like to thank the front-line anti-epidemic personnel, and $82.67 \%$ of the students said they "should study hard and become useful to the society". They believed that "do not believe or spread rumors", "strengthen exercise and improve their immunity", "study hard and do not suspend classes" could best reflect the responsibilities and responsibilities of the students. 
Volume 14 (2021)

Table 4. During the epidemic, from which groups did college students experience the Chinese spirit

\begin{tabular}{|c|c|}
\hline option & proportion \\
\hline Medical staff & $97.19 \%$ \\
\hline youth & $75.64 \%$ \\
\hline Grassroots workers & $86.18 \%$ \\
\hline attendant & $65.57 \%$ \\
\hline army & $77.28 \%$ \\
\hline National staff & $72.60 \%$ \\
\hline other & $2.34 \%$ \\
\hline
\end{tabular}

Table 5. What conceptual impact did the epidemic bring to college Students?

\begin{tabular}{|c|c|}
\hline option & proportion \\
\hline Be proud of your motherland & $93.68 \%$ \\
\hline We should study hard and become useful to society & $82.67 \%$ \\
\hline Thank the brave front-line protesters & $84.54 \%$ \\
\hline Enhanced ecological awareness & $74 \%$ \\
\hline Love life and cherish the present & $77.05 \%$ \\
\hline other & $0.47 \%$ \\
\hline
\end{tabular}

In addition, $94.61 \%$ of the students recognized that the teachers would integrate the "Chinese spirit" into the classroom teaching in the next semester, and $98.59 \%$ of the students thought that the integration of the Chinese spirit into the classroom teaching had a positive impact on them.

From the survey results, "Chinese spirit" undoubtedly has a good incentive effect on students. Students are willing and able to practice the "Chinese spirit" they understand.

\section{Exploration on the Cultivation Path of "Chinese Spirit" of Higher Vocational Students}

As an important part of students' physical and mental development, schools should play an important role in the cultivation of students' "Chinese spirit". From the results of the above questionnaire, we can also find that students are willing to accept the "Chinese spirit" into classroom teaching, and school education is also the most priority channel for them to understand the "Chinese spirit".

Teachers can introduce "Chinese spirit" into Ideological and political teaching, to achieve curriculum ideological and political education and "Chinese spirit" Organic integration of Ideological and political education. Guiding students' Ideological and political education can change the traditional level, simply guide students' Ideological and political education in Ideological and political classroom teaching, and infiltrate ideological and political ideas in different disciplines, to improve students' Ideological and political consciousness at the diversified level. Combined with this epidemic situation, face the "Chinese spirit" at the realistic level Therefore, various examples can be introduced into the curriculum of Ideological and political education, to improve the effect of students' Ideological and political learning.

Teachers can use the typical cases emerging from the epidemic as teaching resources to guide students' Ideological and Political Teaching [1]. This kind of practical case also has a certain understanding and cognition. Compared with the case with a certain sense of time, it has a more sense of substitution for today's students. 
At the level of teaching practice, excessive addition of Ideological and political content will conflict with the theoretical teaching content, and even separate the normal teaching links $[2,3]$ Therefore, in the teaching process, we should reasonably arrange the teaching plan introduced into the ideological and political teaching in combination with the syllabus and teaching objectives, find the classroom teaching rhythm, timely introduce the ideological and political teaching content, and avoid interspersed ideological and political content in the systematic teaching guidance. We can promote the ideological and political teaching content in the course guidance link, and at the end of the classroom The arrangement of curriculum rhythm will not disrupt the normal teaching plan, but also form an appropriate integration between classroom teaching and ideological and political teaching.

For the guidance of students' Ideological and political teaching, in addition to educating them in the classroom, we should also pay attention to the evaluation and reflection of learning effect, which can improve the effect of Ideological and political education and teaching. Teachers can understand the real ability of students' Ideological and political learning through the evaluation link, to make teaching plans from the weak links of students' Ideological and political learning The plan is adjusted so that students can learn ideological and political theoretical knowledge more efficiently and perfectly [4] In terms of the epidemic situation, many good people and good deeds have emerged in the epidemic situation. Teachers can collect materials by themselves and guide students to collect materials by themselves, and then integrate them into a volume, and introduce the anti-epidemic content in each classroom teaching link, so that students can truly feel the "Chinese spirit" during the epidemic situation [5].

\section{Epilogue}

"Chinese spirit" is rooted in the times and in the hearts of each of us Chinese people. Excavating its deep connotation and organically integrating it into future teaching to stimulate their inner "Chinese spirit" can bring good incentive effect and give them additional spiritual strength.

\section{Acknowledgments}

This paper is supported by Zhejiang Zhonghua Vocational education scientific research project in 2021 (ZJCV2021E44): Investigation and Analysis on the cultivation of craftsman spirit in architecture specialty and Research on practical countermeasures.

\section{References}

[1] Yu Yue. Exploration on the practice of Ideological and political collaborative education in Colleges and Universities under the major epidemic [J]. Journal of Zhejiang Wanli University, 2020,33 (04): 96-100.

[2] Wang Wenjing. Integration of epidemic prevention and control practice into college students' Ideological and Political Education [J]. Public relations world, 2020 (12): 136-137.

[3] Yang Zhenfang. Research on the value of integrating anti epidemic Chinese spirit into Ideological and political teaching in Higher Vocational Colleges [J]. Journal of higher education, 2021,7 (26): 15-18.

[4] Luo Jianqin. How novel coronavirus pneumonia is introduced into the ideological and political education in universities? Take "Ideological and moral cultivation and legal basis" as an example, [J]., culture and education materials, 2020 (11): 158-160.

[5] Chi Chengyong. Discussion on the integration of anti-epidemic spirit into Higher Vocational Ideological and political teaching methods [J]. Journal of Shaanxi Youth Vocational College, 2021 (03): 19-24. 